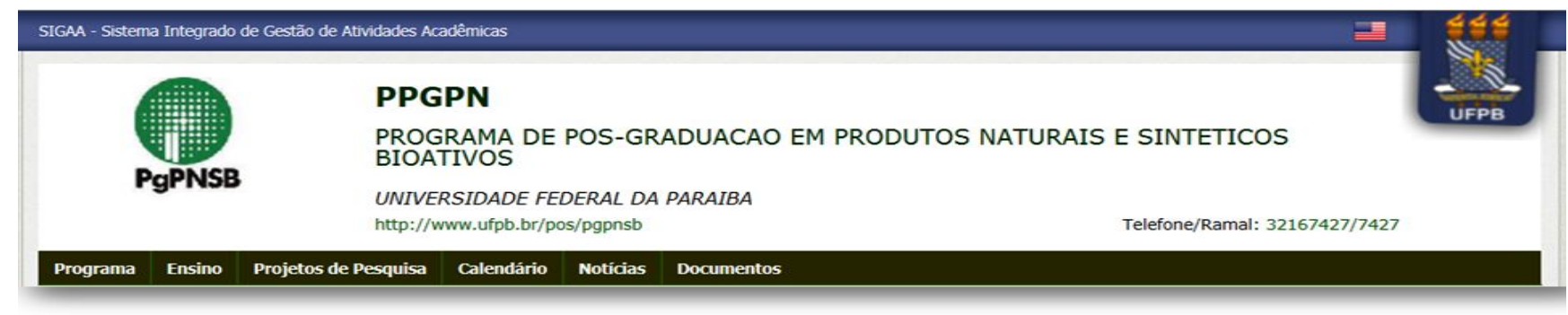

\title{
SciForum
}

MOL2NET

\section{Phytochemical characterization, evaluation of protein content and bioprospection of lectins and trypsin inhibitors in extract of Sesbania virgata (Cav.) Poir Seeds}

Giulian César da Silva Sá ${ }^{1, *}$, Nathália Regina Galvão Silva ${ }^{2}$, Kamila dos Santos Bezerra ${ }^{3}$, Francielly Negreiros de Araújo ${ }^{4}$, Aleson Pereira de Sousa ${ }^{5}$ and Carlos Alberto de Almeida Gadelha ${ }^{6}$

1 Biologist, Master in Cellular and Molecular Biology, PhD Student in Biochemistry, Federal University of Rio Grande do Norte - UFRN; E-Mail: giuliancesarsa@gmail.com

2 Biologist, Master's in Biological Sciences, Federal University of Pernambuco - UFPE; E-Mail: nathaliargalvao@gmail.com

3 Graduate's in Biological Sciences, Federal University of Paraiba - UFPB; E-Mail: kamiilasantoss13@gmail.com

4 Biologist, Master in Cellular and Molecular Biology, Federal University of Paraiba - UFPB; EMail: author2@email

5 Biomedical, specialist in Cytology, Master in Cellular and Molecular Biology, Federal University of Paraiba - UFPB; E-Mail: aleson_155@ hotmail.com

6 Agronomist, Doctor in Biochemistry, Federal University of Paraiba - UFPB; E-Mail: calbgadelha@gmail.com

* Author to whom correspondence should be addressed; E-Mail: giuliancesarsa@ gmail.com; Tel.: +55-999-366-417 (ext. 83).

Received: / Accepted: / Published:

\begin{abstract}
Fabaceae presents 145 subclades and 737 genera. Among them, the genus Sesbania, with about of 500 species, such as Sesbania virgata, whose seeds present high protein content. The present study aimed to characterize phytochemically, to evaluate the protein content and to bioprospect lectins and trypsin inhibitors in the protein extract of Sesbania virgata seeds. Seed meal was used to obtain Total Protein Extract (TPE) in Glycine-NaOH 0.1 mol.L-1 pH 9.0 NaCl $0.15 \mathrm{~mol} . \mathrm{L}^{-1}(1: 15, \mathrm{w} / \mathrm{v})$. After 22 hours of magnetic stirring, the extract was centrifuged (7.076.3 $\mathrm{x} \mathrm{g}, 30 \mathrm{~min}$, and $4{ }^{\circ} \mathrm{C}$ ) and the supernatant collected and named TPE. In this, it was determined the total protein content using the bovine serum albumin standard curve; bioprospecting lectins by hemagglutination assays in rabbit erythrocytes (CEUA/UFPB $n^{\circ} 178 / 2015$ ), and trypsin inhibitors by enzyme assays using the enzyme bovine trypsin; and phytochemical characterization was given by different qualitative tests. TPE presented as protein content 7.13 $\mathrm{mgP} / \mathrm{mL}$ and $106.96 \mathrm{mgP} / \mathrm{gF}$; hemagglutination titers were $32 \mathrm{UH} / \mathrm{mL}$, with $480 \mathrm{UH} / \mathrm{gFa}$ and 4.4887 UH/mgP; not precipitated trypsin inhibitors; and in phytochemical tests, reacted positively to saponins, catechins, flavones, flavonols, xanthones, anthocyanins, anthocyanidins
\end{abstract}


and flavonoids, but reacted negatively to pyrogallic and catechin tannins, leucoantocyanidins, steroids and triterpenes. In other assays performed by our group (data not shown) in which an extract was obtained from buffer Glycine-HCl 0.1 mol.L ${ }^{-1} \mathrm{pH} 2.6 \mathrm{NaCl} 0.15$ mol.L $\mathrm{L}^{-1}$, under the same conditions, it was found that this extraction method was not able of bioprospecting lectins, but favored the precipitation of protease inhibitors. It is understood, thus, that the extraction method influences the obtaining of TPE, the demarcation of considerable protein content and numerous phytochemical compounds, besides the hemagglutination assays suggest the presence of lectins. Together, all these constituents make TPE a versatile biotechnological tool, to check various biological activities.

Keywords: biologically active proteins; hemagglutinating activity; phytochemical constituents; sesbania virgata; lectins; trypsin inhibitors.

\section{Introduction}

The legume seeds are able to provide a diet rich in several nutrients (Torres, 2013), such as Sesbania virgata, a legume (Silva, 2013) with shrub habit (Lisboa et al., 2006), popularly known as black acacia (Branzini, González \& Zubillaga, 2012), saranzinho, mãe-josé and feijãozinho (Araújo et al., 2004), whose seeds contain numerous biologically active proteins (Hossain \& Becker, 2001).

Commonly, legume seeds exhibit biological activities by the mechanism of action of proteins, as the lectins, an antinutritional factor of protein origin with ability to agglutinate erythrocytes and/or to precipitate glycoconjugates (Rüdiger, 1998), mediated by the structure or similarity between the binding sites present on the surface of their membranes (Santana et al., 2008). As well as, protease inhibitors, protein factors with skillful ability to inhibit the catalytic activity of numerous proteolytic enzymes (Neurath, 1989; Ryan, 1990; Brzin \& Kidric, 1995).

The properties displayed by its legume seeds encourage the development of natural or synthetic bioactive products capable of being employed as biotechnological tools. Thus, the present study aimed to characterize phytochemically, to evaluate the protein content and to bioprospect lectins and trypsin inhibitors in the protein extract of Sesbania virgata seeds.

\section{Results and Discussion}

\subsection{Phytochemical analysis}

When present, phytochemicals compounds to express in low intensity, saponins, catechins, flavones, flavonols, xanthones, anthocyanins, anthocyanidins and flavonoids. However, pyrogallic or cathectic tannins did not observed (Table 1), similar to that seen in Coriandrum sativum for catheter tannins (Téllez-López et al., 2017).

Thus, it is possible to infer that the biological activities and bioprospection of biologically active proteins, as they occur without the interference of tannins, in particular, will be free of the possibility of false-positive results, as commonly occurs in lectin activity tests.

Leucoantocianidins, steroids and triterpenes also were not detected (Table 1), suggesting that their non-precipitation is a result of insoluble complexes that form between proteins or carbohydrates present in TPE, as well as by the action of the solvents used.

\subsection{Soluble protein content and bioprospection of lectin and trypsin inhibitors}

The soluble protein content present in TPE was $7.13 \mathrm{mgP} / \mathrm{mL}$ and $106.96 \mathrm{mgP} / \mathrm{mgF}$. Hemagglutination titers were $32 \mathrm{UH} / \mathrm{mL}$, with $480 \mathrm{UH} / \mathrm{gFa}$ and $4.4887 \mathrm{UH} / \mathrm{mgP}$ and the lectin activity is seen with 60 minutes of starting the test and remaining for up to 24 hours after. TPE do not have apparent antitryptic activity.

In other assays performed by our group (data not shown) in which an extract was obtained from buffer Glycine-HCl 0.1 mol. $\mathrm{L}^{-1}$ pH $2.6 \mathrm{NaCl} 0.15 \mathrm{~mol} . \mathrm{L}^{-1}$, under the same conditions, it was found that this extraction method was not able of bioprospecting lectins, but favored the precipitation of protease inhibitors. 
This buffer showed values ranging from $62.99 \%$ to $74.16 \%$ inhibition, and 0.71 and 6.96 $\mathrm{mg}$ of inhibited trypsin/g sample, proving that for Sesbania virgata seeds, it is necessary that this protease inhibitor be extracted in alkaline $\mathrm{pH}$.
While the extract obtained of the Glycine- $\mathrm{NaOH}$ (0.1 mol. $\left.\mathrm{L}^{-1}, \mathrm{pH} 9.0\right)$ containing $\mathrm{NaCl} 0.15$ mol. $L^{-1}$, was chosen as the most effective for to bioprospect lectins.

Table 1. Bioprospection of phytochemical components present in Total Protein Extract obtained from Sesbania virgata seeds. Legend: (-) Negative reaction; (+) Positive reaction.

\begin{tabular}{ccc}
\hline Compound classes & Reactions & Result \\
\hline Pyrogallic and cathectic tannins & Ferric chloride & - \\
Saponins & Chloroform & + \\
Catechins & Colorimetric & + \\
Flavones, flavonols and xanthones & Colorimetric & + \\
Anthocyanins, anthocyanins and flavonoids & Colorimetric & - \\
Leucoantocianidins & Colorimetric & - \\
Steroids & Colorimetric & - \\
Triterpenes & Colorimetric & \\
\hline
\end{tabular}

\section{Materials and Methods}

\subsection{Total Protein Extract (TPE) extraction}

S. virgata (Cav.) Pers. was collected in João Pessoa, Paraiba, Brazil $\left(7^{\circ} 09^{\prime} 51.8^{\prime \prime S}\right.$ 34 54'01.1"W) and deposited in Professor Lauro Pires Xavier Herbarium (JPB n 63198). Healthy and mature seeds were pulverized until a fine flour (FF) was obtained. $1 \mathrm{~g}$ of the FF was homogenized in $15 \mathrm{~mL}$ of Glycine- $\mathrm{NaOH}(0.1$ mol.L $\mathrm{L}^{-1}$, pH 9.0), containing $\mathrm{NaCl} 0.15$ mol.L ${ }^{-1}$. The extract remained for 22 hours of constant magnetic stirring, and centrifuged at $7.076 .3 \mathrm{x} \mathrm{g}$ for 30 minutes, $4{ }^{\circ} \mathrm{C}$ (Eppendorf Centrifuge 5430R). The precipitate was discarded, the supernatant collected and named TPE.

\subsection{Phytochemical partial characterization}

The phytochemical partial characterization was determined by colorimetric reactions, according to methodologies prescribed by Barbosa et al. (2001), Matos (1997) and Robbers et al. (1997).

\subsection{Determination of soluble protein content}

The soluble protein content was determined by colorimetric reactions, using bovine serum albumin as standard and
Coomassie Brilliant Blue G-250 as chromogenic, according Bradford (1976).

\subsection{Lectin and trypsin inhibitors detection assays}

Detection of lectin activity was performed using haemagglutination assays against 3\% rabbit erythrocytes (Debray et al., 1981). The entire procedure was approved by the Ethics Committee for the Use of Animals (CEUA/UFPB, $n^{\circ}$ 178/2015).

Antitryptic activity detection assays, in the presence or absence of trypsin inhibitors, were performed according by Xavier-Filho et al. (1989), using bovine trypsin and DL-BA $\rho N A$ as its chromogenic substrate.

\section{Conclusions}

It is understood, thus, that the extraction method influences the obtaining of TPE, the demarcation of considerable protein content and numerous phytochemical compounds, besides the hemagglutination assays suggest the presence of lectins. Together, all these constituents make TPE a versatile biotechnological tool, to check various biological activities. 


\section{Acknowledgments}

The authors thank the Coordination for the Improvement of Higher Education Personnel (CAPES, Brazil) for the financial support and the scholarship granted to the first author; the Ministry of Science, Technology, Innovation and Communications (MCTIC) and the National Council for Scientific and Technological Development $(\mathrm{CNPq})$ for the financial support to the Laboratory of Structural Proteomics (LaProtE/UFPB).

\section{Conflicts of Interest}

The authors declare no conflict of interest.

\section{References and Notes}

1. Araújo, E.C. et al. Caracterização morfológica de frutos, sementes e plântulas de Sesbania virgata (Cav.) Pers. Revista Brasileira de Sementes 2004, 26, 105-110.

2. Barbosa, W.L.R. et al. Manual para análise fitoquímica e cromatográfica de extratos vegetais. Universidade Federal do Pará: Editora UFPA, Brasil, 2001.

3. Bradford, M.M. A rapid and sensitive method for the quantitation of microgram quantites of protein utilizing the principle of protein dye-binding. Anal Biochemistry 1976, 722, 248-254.

4. Branzini A., González R.S., Zubillaga M. Absorption and translocation of copper, zinc and chromium by Sesbania virgata. Journal of Environmental Management 2012, 102, 50-54.

5. Brzin, J.; Kidric, M. Proteinases and their inhibitors in plants: role in normal growth and in response to various stress conditions. Biotechnology and Genetic Engineering Reveiws 1995, 13,421-467.

6. Debray, H. et al. Specificity of twelve lectins towards oligosaccharides and glycopeptides related to N-glycosylproteins. European Journal of Biochemistry 1981, 117, 41-55.

7. Hossain, M.A.; Becker, K. Nutritive value and antinutritional factors in different varieties of Sesbania seeds and their morphological fractions. Food Chemistry 2001, 73, 421-431.

8. Lisboa, C.G.S. et al. Endo- $\beta$-mannanase from the endosperm of seeds of Sesbania virgata (Cav.) Pers. (Leguminosae): purification, characterisation and its dual role in germination and early seedling growth. Brazilian Journal of Plant Physiology 2006, 18, 269-280.

9. Matos, F.J.A. Introdução à fitoquímica experimental. 2. ed. Fortaleza: EUFC, Brasil, 1997.

10. Neurath, H. Proteolytic processing and physiological regulation. Trends in Biochemical Sciences 1989, 14, 268-271.

11. Robbers, J.E.; Speediem, M.K.; Tyler, V.E. Farmacognosia: biotecnologia. São Paulo: Premier, Brasil, 1997.

12. Rüdiger, H. Plant lectins - more than just tools for glycoscientists: occurrence, structure, and possible functions of plant lectins. Acta Anatomica 1998, 161, 130-152.

13. Ryan, C.A. Protease inhibitor in plants: genes for improving defenses against insects and pathogens. Annual Review of Phytopathology 1990, 28, 425-449.

14. Santana, M.A. Isolamento, propriedades bioquímicas e estudos biológicos da lectina de sementes da Macrotyloma axillare (E. Meyer). Mestrado em Ciências Biológicas, Universidade Federal de Ouro Preto, 2004.

15. Silva, K.B. Características químicas, físicas e biológicas de solos sob Sesbania virgata (Cav.) Pers. Mestrado em Ciência do Solo, Universidade Federal de Lavras, Lavras, 2013.

16. M.Á. Téllez-López, et al. Evaluation of the chelating effect of methanolic extract of Coriandrum sativum and its fractions on wistar rats poisoned with lead acetate. African Journal of Traditional, Complementary and Alternative Medicines 2017, 14, 92-102.

17. Torres, J. Characterization of the nutritive value of tropical legume grains as alternative ingredients for small-scale pork producers using in vitro enzymatic hydrolysis and fermentation. Journal of Animal Physiology and Animal Nutrition 2013, 97, 1066-1074.

18. Xavier-Filho, $\mathrm{J}$ et al. Poor correlation between the levels of proteinase inhibitors found in seeds of different cultivars of cowpea (Vigna unguiculata) and the resistance susceptibility to predation by Callosobruchus maculatus. Journal of Agriculture and Food Chemistry 1989, 37, 1139-1143. 